\title{
Nadia's nectar
}

\section{The fountain of youth.}

\section{Ian Watson}

Nadias Nectar poured over cubes of watermelon makes a delicious breakfast!

"We'll try that!"

Nadia Peartree was the toast of Hollywood by 2015! Two Golden Globes, and we ain't referring to her bosom, plus two Oscars -!

"Mom, I'm trying to do Tyrannosafari on my fone.s

"Just eat your toast, Pumpkin, and drink your nectar."

Plus, Nadia was Born Again, so when she quoted Solomon's Proverbs 5:15, 'Drink water from your own cistern,' America listened. And bought - !

"Honey, if you'tl quit fondling that T-Pak, it'll shut up."

Would you believe that at the turn of the twenty-first century only three million Chinese drank urine; and those Brahmins in India and in the West folks who were yoga fanatics - ?

"But it's a new touchy-talkchip, Bert. $^{\text {. }}$

Yes, folks, pee-prejudice blinded most of us to a pedigree going back to ancient Israel and Tibet, whose lamas lived to a ripe old age because of pee, which rhymes with immortalitee! Gandhi drank his own urine, and he beat the British -

"Honey, I'm sick of every darn food and drink voicing off - 'watch out, I expire next week, by the way tortoises can live 200 years, well I ain't no tortoise' - yabber yabber."

They say Steve McQueen lived on urine and boiled alligator skin while he was fighting the big C -

"Bert, I never knew that."

Though most likely Nadia was inspired by Paul Newman's Organic Foods, what with all his royalties after tax, hundreds of millions, going to education and charity work. Remember Pa Newman and his daughter dressed up on those packets of healthy pretzels and choc bars and alphabet cookies looking American Gothic? Wholesome traditional virtues! Funnily enough, an FAQ was, 'Do you use slave labour in producing your chocolate?' What a question! Of course not! The welfare of producers of the raw material was paramount (and I don't mean as in Pictures!). Nadia thought even more deeply about the welfare of producers in the Third World -

"Mom, I can't hear if a Tyranno's coming."

${ }^{\alpha}$ Pumpkin, I'm just pouring myself a little more."
"Yeah, drip by drip."

This was the philanthropic clincher! Only naive buyers of Nadia's Nectar could think they were quaffing urine solely passed by the star herself - leaving aside that 'passed' also means 'approved'! Good wholesome urine has to be sourced in considerable bulk, pasteurized and frozen for shipment. Where better, than from the poverty-stricken lands of Central America? What a godsend to so many people in those nations!

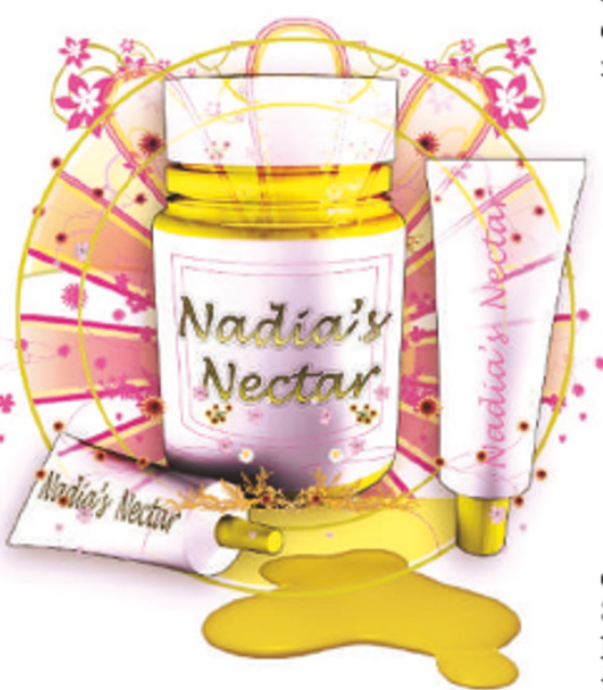

"Oh zipyour lip, T-pak."

"It ain't got ears or lips, $\mathrm{Pa}$."

For the urine to be first rate, the donors all need to be in tip-top health, kept supplied with all necessary nutrition, vitamins and minerals in exchange for their urine. The Man from Nadia's Nectar doesn't visit joyful producers to slice open a sample fruit with a machete! No, he's there all the time with a biochem test kit to check up on everyone, and a good nose for the bouquet of quality urine. It's famous that Nadia maintains the most wonderful health clinics in the source areas.

"Just hear a bit more, Bert?"

Nadia also contributes directly to her product, even now, when she's in her late fifties, though looking a million dollars, needless to say. Into every hundred pints goes a droplet of her own urine. Byhomeopathic principles this intensifies the effect! All consumers know that they're participating directly in Nadia's glamour.

In the old days you'd hear silly objections that you couldn't get much in the way of urokinase or assorted hormones and antibodies and magnesium, calcium, potassium, out of quaffing a pint of pee - and also that the body was peeing stuff out because it alreadyhad enough inside it, that it actively wanted rid of the stuff. Tell that to a two-hundred year old lama.

"How much more?"

"But Bert, welove Nadia."

"I'm drinking her, ain't I?"

Did ya know how good-ole Enzymes of America used to fit special filters to 10,000 Porta-Johns to recover an enzyme that dissolves blood clots? Fourteen million gallons of pee going into Porta-Johns each year meant quarter of a million coronary arteries unblocked! There was a half-

billion-dollar annual market for urine products. But until Nadia's Nectar, that was an invisible market, a silent one. Pee products were hidden in pills and small print. $\mathrm{Oh}$, and in beauty products and soaps - urine breaks down grease in hair, fr' instance.

Who cares if some other former Oscar-winners copied Nadia with rival brands, and quirky flavours and colours? For my money nothing beats Nadia’s Original Nectar.

If your eyes are tired, give them a few drops of her urine. Aching ears? Likewise. Sinuses congested? Sniff the golden juice! Drink water from your own well! Or better, from Nadia's. The Bible says so, and Nadia made sure we got the message.

$\mathrm{Oh}$, the early commercials were so classy! Elegantly nightgowned Nadia going into her personal bathroom in her Malibu mansion just after sunrise and closing the door while the tinkly Trout Quintet played, then coming out smiling gorgeously carrying a beaker of golden liquid, which an aide promptly rushed away to safeguard its freshness. A genuine classic. Any of you remember?

"Me, I do!"

The modern commercials are pretty neat too. Nadia does most ads personally and never uses a rejuved CGI clone. She's utterly for real. That's why most people prefer her urine to their own. Trust. Drinking her pee's a communion.

Is it a wrap, guys? Did I read it good?

"Goofs, they oughta edited that bit out."

"No, Bert, it's gotta be a deliberate mistake. There'll be a prize for noticing! Pumpkin, pass me your fone.

lan Watson wrote the screen story for Spielberg's A.I. Artificial Intelligence. His next story collection is The Butterflies of Memory (PS Publishing, June 2006). $\mathrm{His}$ website with funmy photos is at www.ianwatson.info. 